\title{
Mathematical Model of Hybrid Precast Gravity Frames for Smart Construction and Engineering
}

\author{
Seon-Chee Park, ${ }^{1}$ Won-Kee Hong, ${ }^{1}$ Sunkuk Kim, ${ }^{1}$ and Xiangyu Wang ${ }^{2,3}$ \\ ${ }^{1}$ Department of Architectural Engineering, Kyung Hee University, 1732 Deogyeong-daero, Giheung-gu, Yongin-si, \\ Gyeonggi-do 446-701, Republic of Korea \\ ${ }^{2}$ Australasian Joint Research Centre for Building Information Modelling, Curtin University, GPO Box U1987, Perth, WA 6845, Australia \\ ${ }^{3}$ Department of Housing and Interior Design, Kyung Hee University, 1732 Deogyeong-daero, Giheung-gu, Yongin-si, \\ Gyeonggi-do 446-701, Republic of Korea \\ Correspondence should be addressed to Won-Kee Hong; hongwk@khu.ac.kr
}

Received 28 February 2014; Revised 4 April 2014; Accepted 1 May 2014; Published 27 August 2014

Academic Editor: Changzhi Wu

Copyright (c) 2014 Seon-Chee Park et al. This is an open access article distributed under the Creative Commons Attribution License, which permits unrestricted use, distribution, and reproduction in any medium, provided the original work is properly cited.

\begin{abstract}
The structural stability, constructability, economic feasibility, environmental-friendliness, and energy efficiency of hybrid composite frame systems have been demonstrated by practical application and research. A hybrid composite frame system combines the economy of precast concrete structures with the constructability of steel frame structures, including erection speed. Novel composite frames will ultimately maximize the efficiency of structural design and facilitate construction. This paper presents hybrid precast frames, which are precast composite frames based on a simple connection between precast concrete columns and beams. The hybrid precast frames designed to resist gravity loading consist of PC columns, PC beams, and steel inserted in the precast members. Steel sections located between the precast columns were simply connected to steel inserted at each end of the precast beams. Dynamic analysis of a 15-story building designed with the proposed composite frame was performed to determine the dynamic characteristics of a building constructed of hybrid frames, including frequencies and mode shapes.
\end{abstract}

\section{Introduction}

The use of hybrid precast composite frames with hybrid precast beams and columns for gravity loading offers advantages of both steel and precast concrete materials. Effective interaction between the two materials facilitates a reduction in size of both hybrid precast beams and columns. The hybrid precast frames are connected by simple connections that support only gravity load.

In a previous study, Hajjar (2002) demonstrated the benefits of composite systems relative to more common systems [1]. Such advantages were determined by comparing the performance characteristics of beams subjected to service and ultimate loads. Hajjar also analyzed the economic benefits of composite structures with respect to material usage and construction costs. Fabbrocino et al. (2001) used a refined theoretical model to investigate the influence of steel reinforcement on the rotational capacity of composite beams under negative bending [2]. This model was validated through experimental testing. Yang and Tan (2014) conducted a series of experiments to investigate the failure modes and ductility of composite beam-column joints under a middle-column-removal scenario and reported the ductility and load resistances of these five specimens in catenary action. They found that strengthened web cleat connections had a much higher load-carrying capacity than normal web cleat connections because the former could sustain greater deformation [3]. Tesser and Scotta (2013) studied composite steel trusses and concrete beams with an inferior precast concrete base and compared their findings with theoretical evaluations of typical resistance mechanisms of steel-concrete composite and reinforced concrete structures. They discussed the main qualitative and quantitative features of the composite steel truss and concrete beams [4]. Hwang and colleagues (2011) evaluated the seismic resistance of concrete-filled, Ushaped steel beam-to-RC column connections and provided 
seismic details of concrete-encased, U-shaped steel beam-to$\mathrm{RC}$ column connections. The specimens exhibited required strength, deformation, and energy dissipation capacities. The deformation capacity exceeded an interstory drift angle of $4 \%$, which is a requirement for special moment frames [5]. Hassan and Khosrow (2011) presented an analytical investigation based on FE models and using ANSYS software to examine the effectiveness of a precast beam column concrete connection of a jointed system. However, this computer model did not examine the steel section installed in a columnbeam joint, as discussed in [6]. Another study by Ioani and Tripa (2012) discussed a new all-precast concrete system used in Romania to construct a residential building. Designed for constructability, a new all-precast concrete system comprising columns, flat slabs, and structural walls were proposed. To validate the structural quality and performance of this type of structure, an extensive program of theoretical analyses and structural tests (including shake table tests) was conducted [7]. This product proposed by Ioani and Tripa differs from the one proposed here. The structural system developed by the authors is a hybrid composite beam-column frame that demonstrates the structural behaviors of building frame system. We designed hybrid precast composite frames with simple steel connections inserted between precast concrete columns and beams to resist only gravity loading. The first objective of the study by Chou and Uang (2007) was to examine the effects of the two factors of continuity plates and the amount of transverse reinforcement on the concrete shear strength in the connection region. The second objective was to develop an analytical procedure to quantify the connection shear force developed in concrete. This continuity plate will be used for the hybrid composite frames of the authors in later experiments [8]. Ju and Kim (2005) developed the technical, economical, and convenient (TEC) composite beam with experimental investigation using a series of monotonic loading tests [9]. However, this beam is not free from the requirement of being fire-proof. These studies did not expand their interests to hybrid composite structures for practical applications which were covered in this paper. We also present novel structural systems with dynamic analysis to examine the hybrid behavior of a building, which takes advantage of material, structural, and construction hybrid features and capabilities. The hybrid precast composite frame system shows how material, structural, and construction hybridity are established to uniquely provide economy and constructability, making this technology significant to the construction industry. We also designed hybrid precast composite frames with simple steel connections inserted between precast concrete columns and beams to resist only gravity loading. The hybrid composite frame system introduced in this paper is intended to provide the economy of precast concrete structures with the constructability of steel frame structures. Structural design efficiency, facilities planning, construction, and building management could be maximized using the proposed composite frame system. Implementation of integrating augmented reality with building information modeling [10-13] will help project the schedule and cost of construction utilizing smart frame for site engineers and responses to any demand for changes can be provided in time.
We have previously $[14,15]$ investigated dual-frame systems composed of hybrid precast frames. The dual-frame system consists of a moment frame and a bearing wall or braced frame. Seismic forces are distributed in proportion to the lateral stiffness of each frame. The moment frame has to resist at least $25 \%$ of the design seismic forces. However, the dual frame systems with moment connections including much more complicated construction details require significant time and costs than simple connections which are used in building frame systems for gravity loadings. Building frame systems with simple connections are commonly used with steel frames to provide fast and easy construction for buildings. In this paper, new structural system to provide simplified construction method was presented for building frame systems for gravity loadings fabricated with hybrid precast composite frames consisting of simple connections between columns and beams.

The building frame system was designed for the research; the frames resist gravity loading, while the bearing walls resist lateral forces.

\section{Precast Composite Structural System (Hybrid Precast Frames)}

2.1. Details of the Frame with Generalized Steel Joints. The hybrid precast frames proposed in this study represent a hybrid composite structural system with the advantages of both steel frames and reinforced concrete structures. Hybrid precast frames are composed of generalized steel joints, reinforcing steel, and precast concrete. Apartment buildings have been outfitted with these hybrid precast frames to resolve problems such as the increase in floor height when constructed with concrete Rahmen. These frames can maintain the same floor height as that of a bearing wall system, providing architectural flexibility and cost-effectiveness $[14,15]$. We developed a precast steel column with steel connections to effectively erect and assemble the composite frames. The joints of hybrid precast frames installed to a corewall were simple connections to support vertical loadings only. The joints of the gravity frames were not filled with concrete, allowing for pin-joint behavior, which enhances the constructability and economic feasibility of the gravity frames. The construction of the core-walls was followed by construction of hybrid precast frames, including columns, beams, and slabs. Hybrid precast frames were composed of hybrid precast beam units and hybrid precast column units with enhanced joint connections capable of resisting vertical loads, enabling more efficient erection with structural stability. Specifically, the introduction of steel sections for joint connection makes the construction of hybrid precast frames as timely as that of steel frames. Hybrid precast frame construction is illustrated in Figure 1.

Hybrid precast frames were manufactured either at a plant or on site [16]. Hybrid precast beams take advantage of the material properties of both steel and precast concrete without sacrificing the performance of the composite beams. The depths of the beam and slab can also be reduced when slabs are constructed on the edges of precast concrete. 

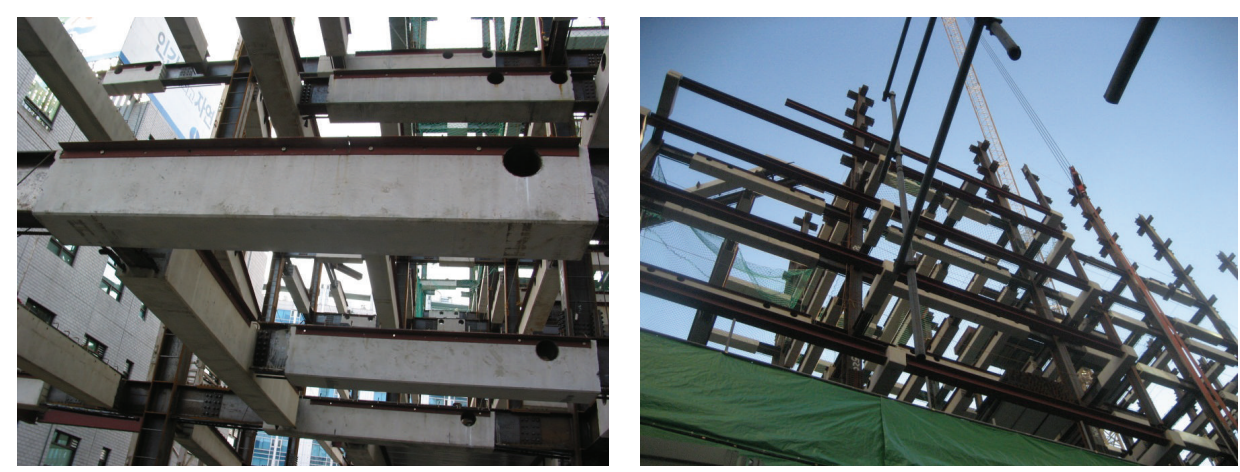

FIGURE 1: Building construction with hybrid precast frames.


FIgURE 2: Detailed information on beam-column joint members.

Figure 2 shows the beam-column joint connection of hybrid precast frames, where joint connections are not filled with concrete (i.e., pin-joint). Typical hybrid precast beam-column connections designed for pinned conditions (Figure 2) enable the gravity load to be transferred through the joints where the web of steel beams is bolted to the steel section of the hybrid precast column. This type of structural frame system provides simpler construction with structural stability to support gravity loads.

Figure 3 shows the generalized steel joints configured for gravity loading that are used in the hybrid precast frames. Additional shear taps are installed to provide connections between the steel sections from both columns and beams. Steel sections inserted into the hybrid precast beams and columns allow hybrid precast frames to be erected in as many as three stories at a time. Conventional steel joints used in conventional steel construction are utilized as generalized connections.

Figure 4 shows the construction process used to produce the hybrid precast frames. Both the hybrid precast column and the beam units of the hybrid precast frames were manufactured as two-story or three-story column units and were erected in one cycle. The main processes of floor work, which took about four days, consisted of marking, core wall reinforcement work and form installation, installation of hybrid precast column units and beam units, installation of deck plates or a PC plate and joint form, slab reinforcement work, and pouring. 


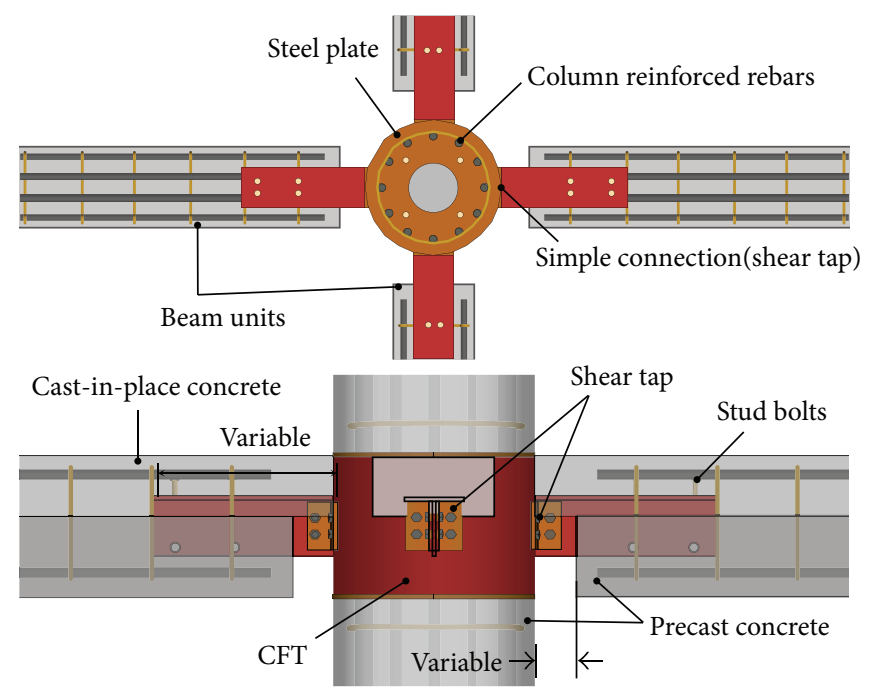

(a) Details of the beam-column joints of the hybrid precast frames

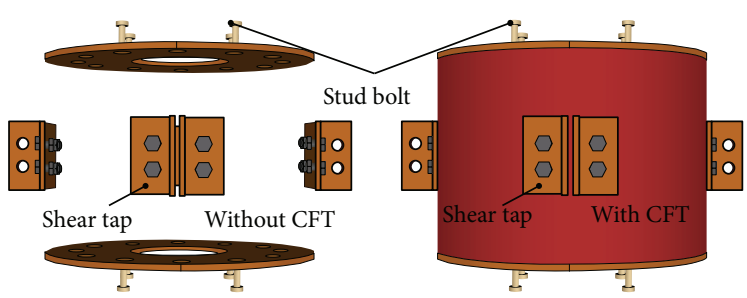

(b) Details of the shear tap

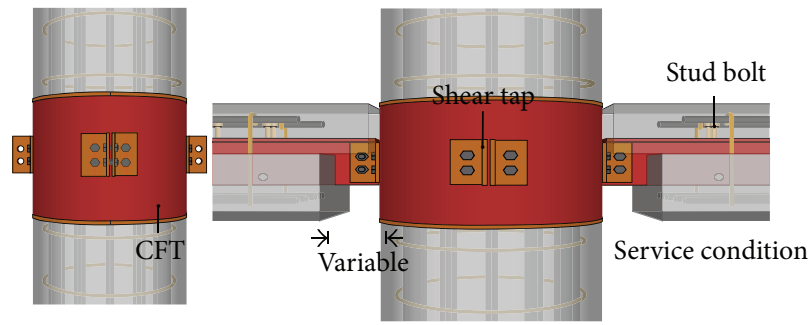

(c) Construction details of the column unit

FIGURE 3: Details of the hybrid precast frame joints.

Precast structures cannot be erected as fast as steel structures because beams without slabs lack stability, as shown in Figure 5. The hybrid precast frames, however, can be erected as quickly as steel structures without slab construction. The hybrid precast frames suggested in this paper are hybrid composite structures that have the merits of both steel and precast concrete structures; in particular, the steel sections function as erection components. This hybrid construction method makes it possible to erect precast concrete frames in a time-frame similar to that of steel frames.

2.2. Structural Stability during Construction. The proposed hybrid precast frames with steel joints provide structural stability during construction. In contrast, the vertical reinforcing steel used for vertical splicing in conventional precast applications is vulnerable to buckling against unexpected vertical loading before the joints are filled with concrete, which could cause structural instability of the frame under construction, as shown in Figure 6. In the proposed method, steel sections are inserted between the upper and lower precast columns and are connected to steel sections located at both ends of the precast beams and girders or steel sections running throughout the entire lengths of the precast beams, allowing easy and stable connections.

\section{Use of Convergence of the Hybrid Precast Frames}

Because hybrid precast frames can be designed using a wide range of spans and joint designs, bearing wall-type apartment buildings may be replaced with buildings with hybrid precast frames. Structural systems should be optimized with steel connections, which are required to be as small as 20 $25 \mathrm{kgf} / \mathrm{m}^{2}$ (about one-tenth that of reinforcing steel), enabling constructability and assembly time similar to that of steel frames.

Figure 7 shows deflections of a composite frame building subjected to wind loads. The lateral displacements are within acceptable limits. Displacement along the $x$-axis and $y$ axis was $20 \mathrm{~cm}(\mathrm{H} / 3910)$ and $29 \mathrm{~cm}(\mathrm{H} / 1955)$, respectively. Acceptable story drift in response to seismic loading was also observed in both directions, as shown in Figure 8. These results demonstrate that the optimized structural composite frames have structural stability.

\section{Dynamic Analysis of a Building with Hybrid Precast Frames}

Figure 9 shows a building with 13 stories and two basements (total floor area of $6741 \mathrm{~m}^{2}$ ) that was designed with 


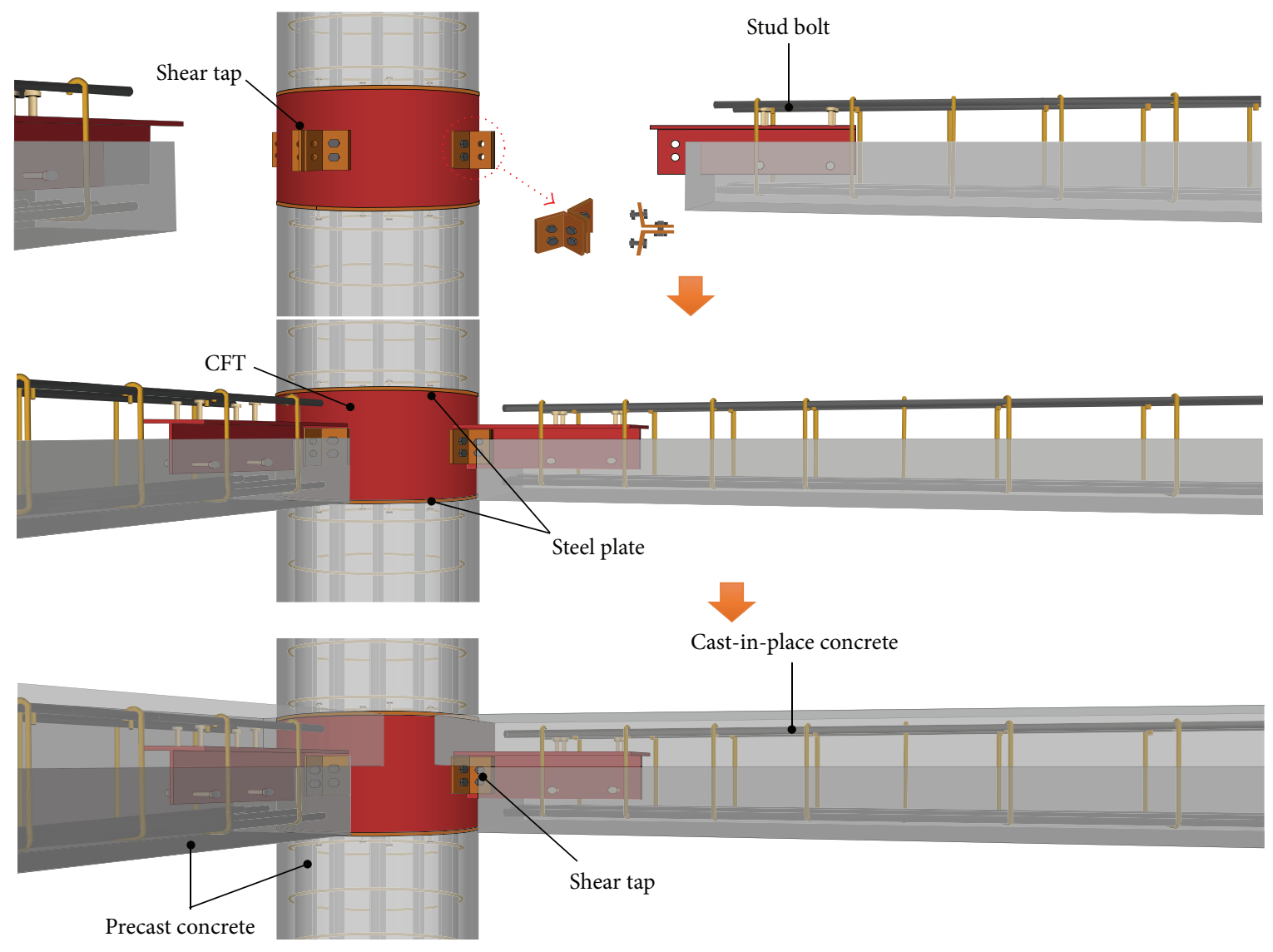

FIGURE 4: Hybrid precast frame construction process.
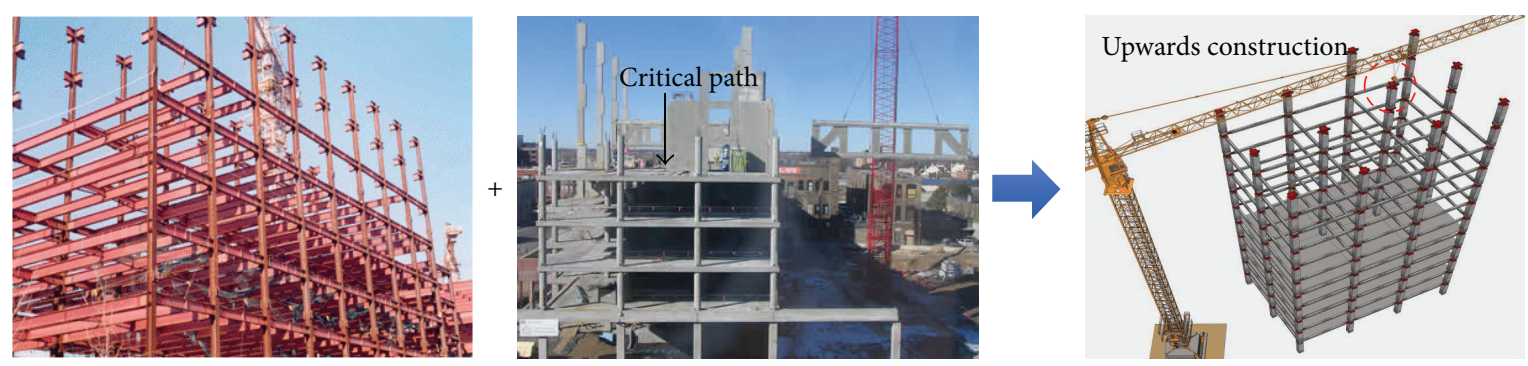

FIGURE 5: Reduction of the hybrid precast frame construction period.

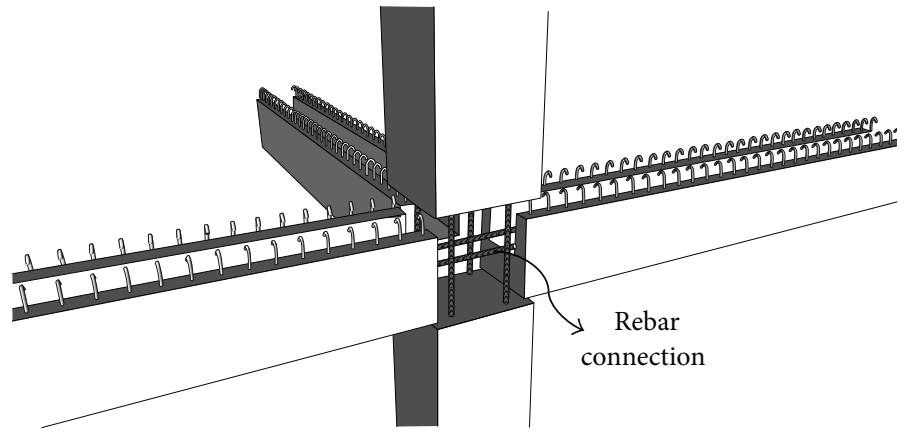

(a)

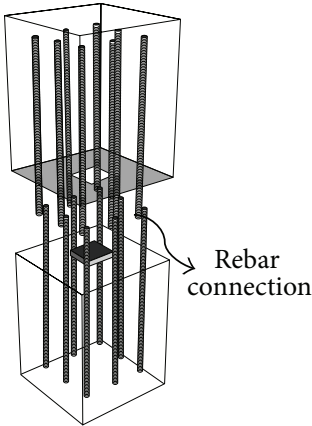

(b)

FIGURE 6: Conventional precast concrete connections. 


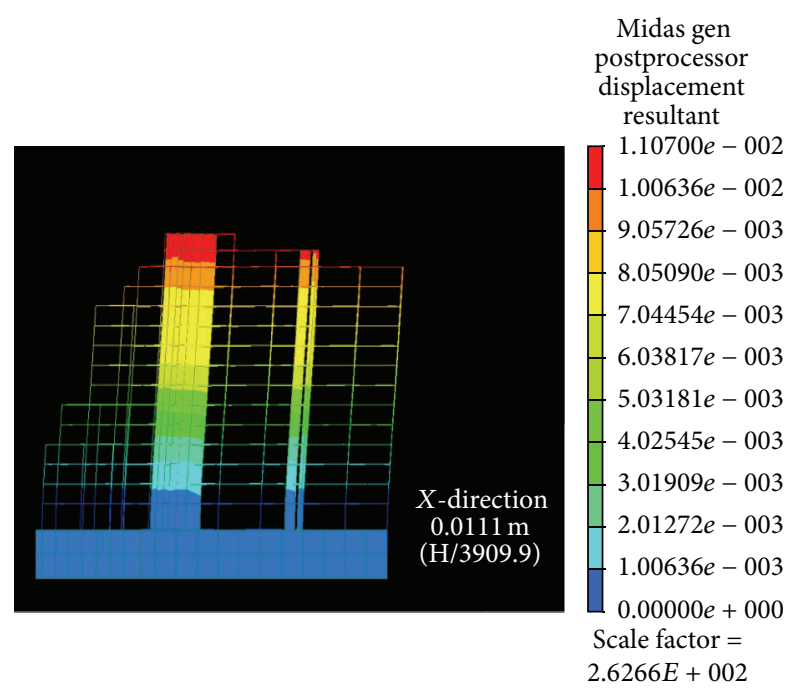

(a)

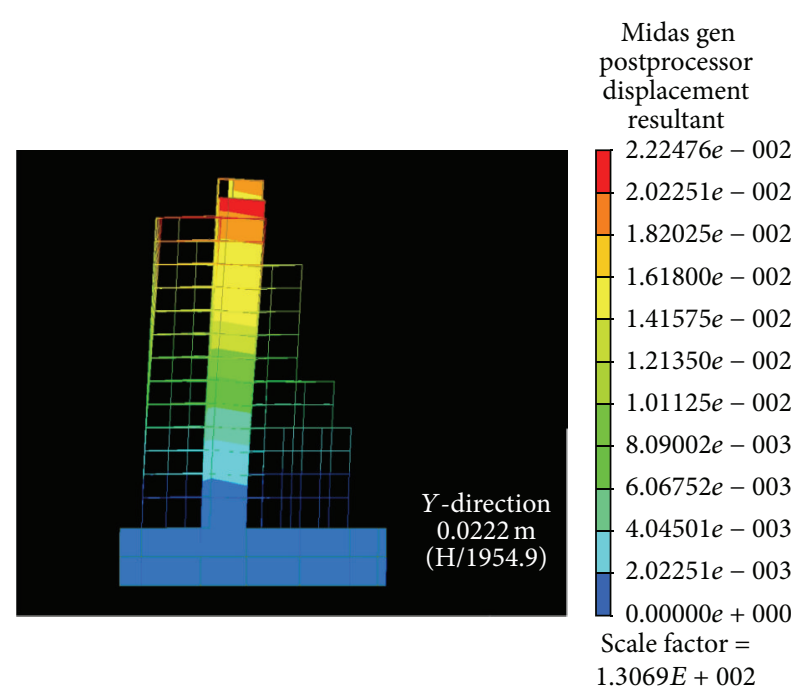

(b)

FIGURE 7: Wind displacement.

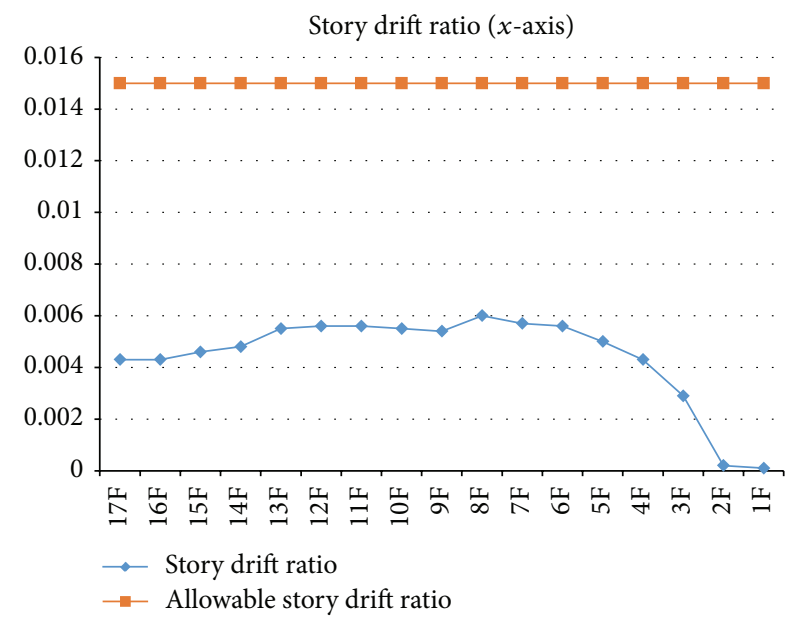

(a)

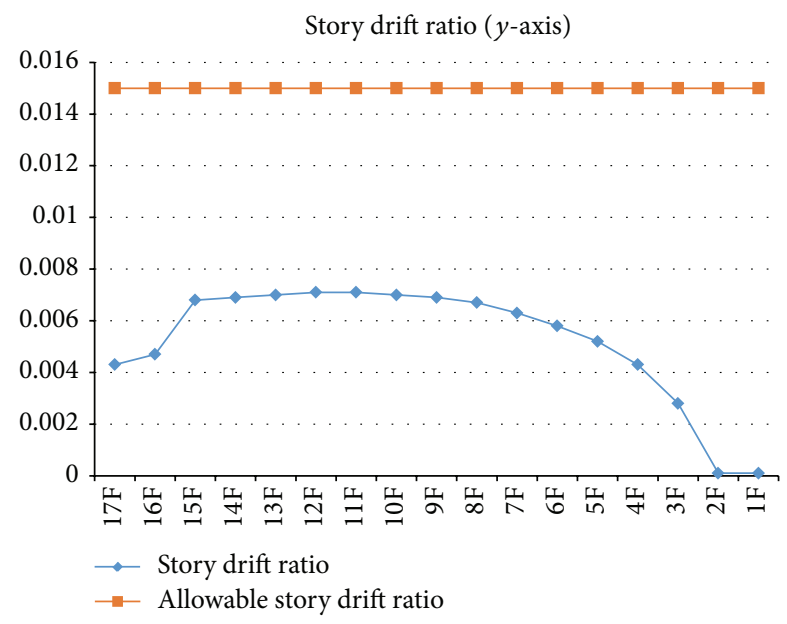

(b)

Figure 8: Story drift.

the proposed composite frames and selected for dynamic analysis. The floor plan and elevation with framing using composite columns and beams are also shown. The building was designed such that the shear walls were resistant to lateral seismic loadings, while the frames resisted only vertical loads. Dynamic analysis was performed to investigate the influence of the design and size of the composite frames on the dynamic characteristics of the building.

Figure 10 shows a computer model of the building with composite frames and walls in which the steel sections at both ends of the beams are connected to steel inserted between two precast columns. Figure 10(a) shows gravity composite frames attached to shear walls that are responsible for lateral earthquake loading. Figure 10(b) shows close connection details of the frames and walls that constitute the building frame. Figure 10(c) shows steel frames and connections between beams and columns. The material, structural, and construction hybrid applications were integrated to combine the constructability of steel structures with the economy of concrete structures.

Tables 1 and 2 show modal participation masses and eigenvalue results, respectively. The fundamental translational mode was found in the third return period; the first and second modes were considered to be mixed translational modes with torsion. A fundamental translational mode of 1.5 seconds along with a weak $y$-axis was deemed reasonable. The fundamental period and mode shapes for the composite frame were more similar to those of steel structures than those of concrete structures, indicating that the structural behavior of a building with composite frames and steel 


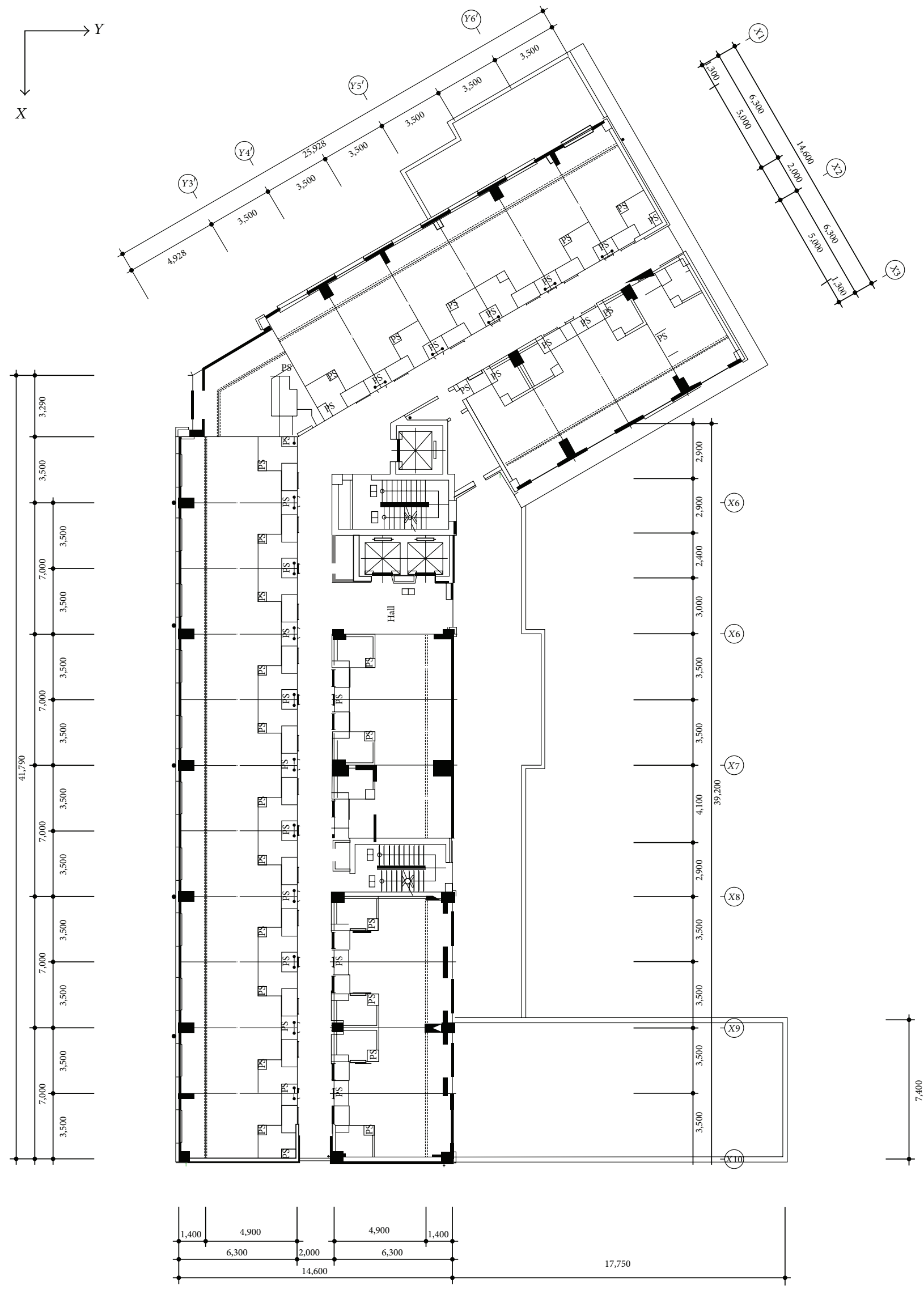

(a)

Figure 9: Continued. 


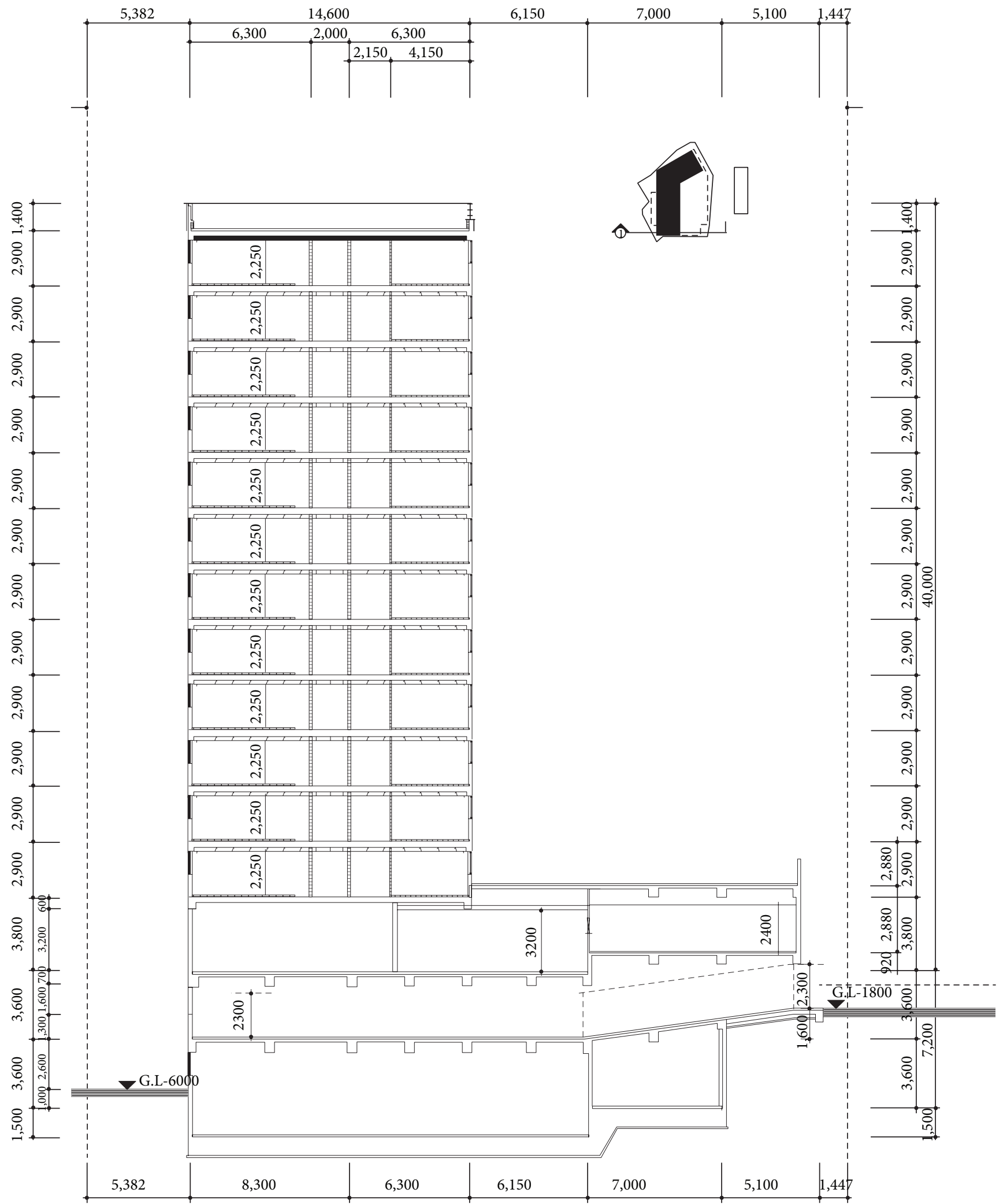

(b)

FIGURE 9: Floor plan and elevation. 
TABLE 1: Modal participation masses.

\begin{tabular}{|c|c|c|c|c|c|c|}
\hline \multirow{2}{*}{ Mode number } & \multicolumn{2}{|c|}{ TRAN- $X$} & \multicolumn{2}{|c|}{ TRAN-Y } & \multicolumn{2}{|c|}{ ROTN-Z } \\
\hline & Mass (\%) & Sum (\%) & Mass (\%) & Sum (\%) & Mass (\%) & Sum (\%) \\
\hline 1 & 40.5909 & 40.5909 & 0.2185 & 0.2185 & 12.7252 & 12.7252 \\
\hline 2 & 4.2570 & 44.8478 & 16.208 & 16.4265 & 20.3361 & 33.0612 \\
\hline 3 & 4.0667 & 48.9145 & 32.8629 & 49.2893 & 8.2552 & 41.3164 \\
\hline 4 & 9.6703 & 58.5848 & 0.1847 & 49.474 & 4.0557 & 45.3721 \\
\hline 5 & 3.2088 & 61.7935 & 0.3965 & 49.8705 & 8.7600 & 54.1321 \\
\hline 6 & 0.3685 & 62.1620 & 15.8676 & 65.7381 & 0.5207 & 54.6528 \\
\hline
\end{tabular}

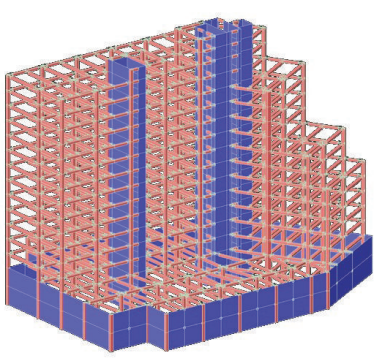

(a)



(b)

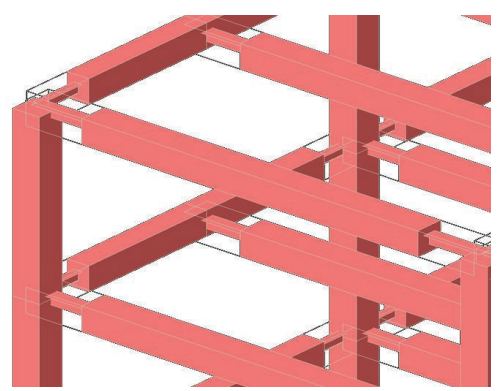

(c)

FIGURE 10: Computer model of the building.

TABLE 2: Eigenvalue analysis (fundamental period).

\begin{tabular}{lcccc}
\hline Mode number & \multicolumn{2}{c}{ Frequency } & Period & Tolerance \\
& $(\mathrm{rad} / \mathrm{sec})$ & $(\mathrm{cycle} / \mathrm{sec})$ & $(\mathrm{sec})$ & \\
\hline 1 & 3.4768 & 0.5533 & 3.4768 & $0.0000 e+000$ \\
2 & 4.1078 & 0.6538 & 4.1078 & $0.0000 e+000$ \\
3 & 5.3487 & 0.8513 & 5.3487 & $0.0000 e+000$ \\
4 & 13.8311 & 2.2013 & 13.8311 & $4.5251 e-161$ \\
5 & 17.8259 & 2.8371 & 17.8259 & $2.8518 e-150$ \\
6 & 23.6726 & 3.7676 & 23.6726 & $1.5909 e-137$ \\
\hline
\end{tabular}

joints against vertical and lateral loadings resembles that of steel structures, even though the building has an external appearance of a concrete structure.

Figure 11 shows the first translational mode (a) and those of two mixed modes ((b), (c)). Figures 11(d), 11(e), and 11(f) show these modes from the top view, respectively.

\section{Reduction of Structural Quantity and Emissions of Environmentally Hazardous Substances and Materials}

This study evaluated chromium VI and carbon dioxide emissions of the building constructed with the proposed frames and conventional walls. Reductions in energy consumption due to reduction in material quantity were estimated based on comparison of an apartment building constructed with hybrid precast frames and that of a conventional bearing-wall building.

Original units of major building components (Table 3), which were announced in 2008 by the United Kingdom
TABLE 3: Emissions and energy usage of major building components [17].

\begin{tabular}{lcc}
\hline $\begin{array}{l}\text { Building } \\
\text { component }\end{array}$ & $\begin{array}{c}\mathrm{CO}_{2} \text { emissions } \\
\text { per original unit }\end{array}$ & $\begin{array}{c}\text { Energy consumption } \\
\text { per original unit }\end{array}$ \\
\hline Concrete $25 \mathrm{MPa}$ & $319.6 \mathrm{~kg}-\mathrm{CO}_{2} / \mathrm{m}^{3}$ & $2326.5 \mathrm{MJ} / \mathrm{m}^{3}$ \\
Concrete $35 \mathrm{MPa}$ & $378.35 \mathrm{~kg}-\mathrm{CO}_{2} / \mathrm{m}^{3}$ & $2655.5 \mathrm{MJ} / \mathrm{m}^{3}$ \\
Reinforcement & $273.19 \mathrm{~kg}-\mathrm{CO}_{2} / \mathrm{kN}$ & $3710.50 \mathrm{MJ} / \mathrm{kN}$ \\
Steel section & $283.38 \mathrm{~kg}-\mathrm{CO}_{2} / \mathrm{kN}$ & $3751.27 \mathrm{MJ} / \mathrm{kN}$ \\
\hline
\end{tabular}

Inventory of Carbon and Energy (ICE), were used to evaluate carbon dioxide emissions and the energy efficiency of the proposed construction. The embodied energy $E$ and carbon emissions per $\mathrm{kN}$ for the calculated material quantity are obtained from the University of Bath's ICE database [17, 18]. The ICE has been structured into 34 main material groups. The database also provides the embodied energy and carbon coefficients for construction materials. Table 3 presents the converted embodied energy and carbon coefficients for four building components: concrete (25 MPa), concrete (35 MPa), reinforcement, and steel section.

Domestic and foreign cement heavy metal analysis results (May 2013) published by the Korea National Institute of Environment Research (NIER) were utilized to evaluate chromium VI emissions (Table 4).

In order to explain how the data that evaluates the gravity system presented in this paper in terms of material quantity, analytical approach for the hybrid precast composite beam design based on the strain compatibility method was introduced. Figures 12 and 13 illustrate the side view and crosssection of a hybrid composite beam. In order to determine the 
TABLE 4: Heavy metal content standards in cement [19].

\begin{tabular}{lcccccc}
\hline & $\mathrm{Cr}^{6+}$ & $\mathrm{As}$ & $\mathrm{Cd}$ & $\mathrm{Cu}$ & $\mathrm{Hg}$ & $\mathrm{Pb}$ \\
\hline Ave. (May, 2013) & $10.63 \mathrm{mg} / \mathrm{kg}$ & $12.87 \mathrm{mg} / \mathrm{kg}$ & $1.02 \mathrm{mg} / \mathrm{kg}$ & $89.03 \mathrm{mg} / \mathrm{kg}$ & $0.61 \mathrm{mg} / \mathrm{kg}$ & $32.84 \mathrm{mg} / \mathrm{kg}$ \\
\hline
\end{tabular}

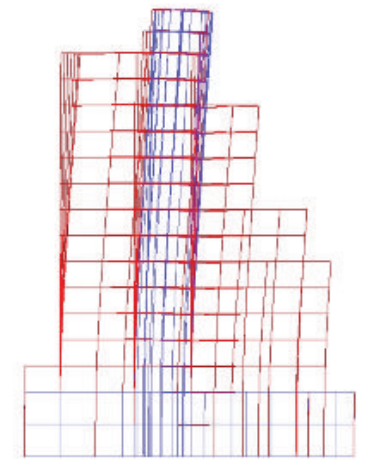

(a) Fundamental translational mode

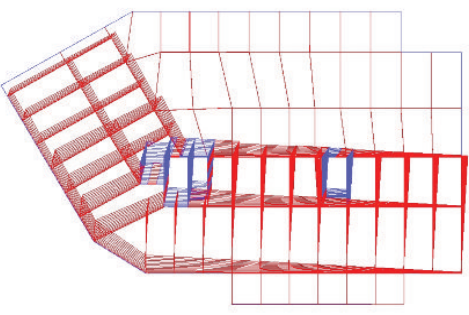

(d) Fundamental translational mode

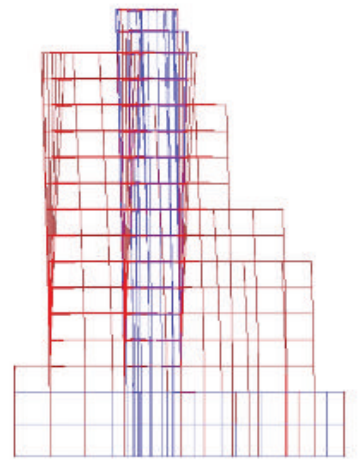

(b) Mixed mode 1

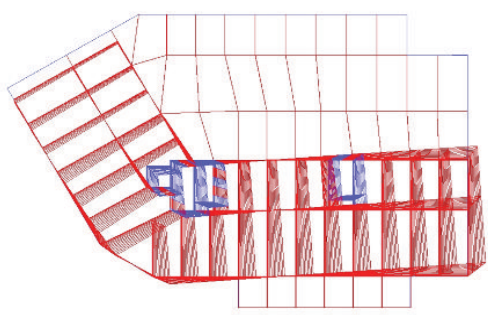

(e) Mixed mode 1

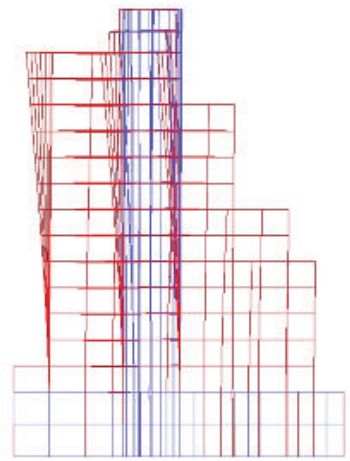

(c) Mixed mode 2

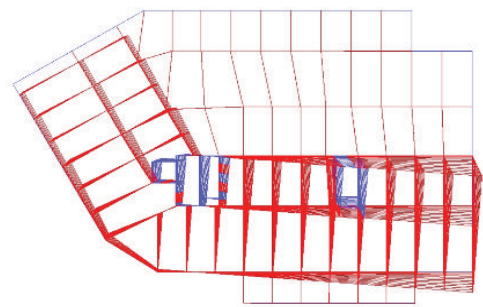

(f) Mixed mode 2

FIGURE 11: Mode shapes.

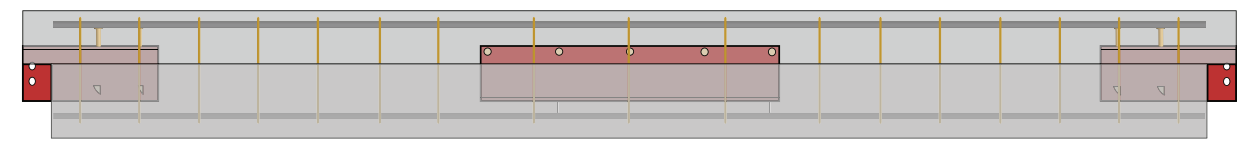

Figure 12: Side view of a hybrid composite beam.

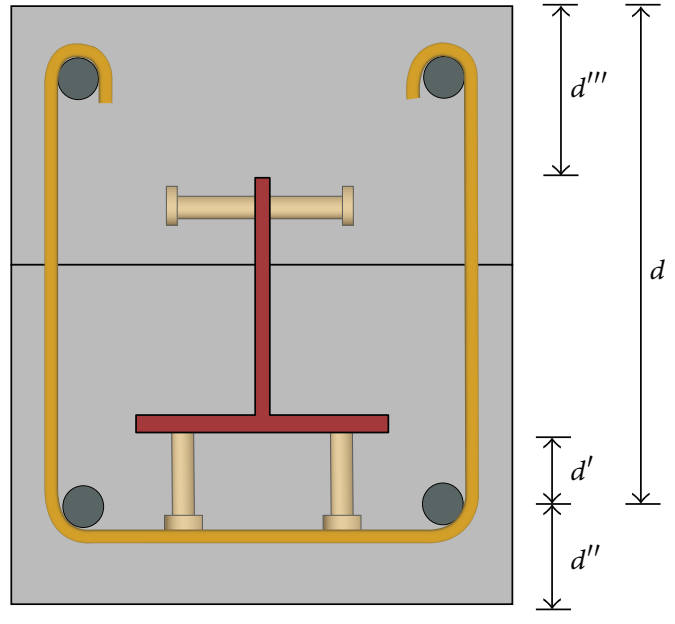

FIGURE 13: Cross-section of a hybrid composite beam. exact material quantity, the hybrid composite beam design was carried out based on the strain compatibility method. Equations (1) and (2) are the mean stress factor $\alpha$ and the centroid factor $\gamma$ for any strain $\varepsilon_{c m}$ at the extreme compression fiber calculated based on stress-strain relationship. Equations (3) and (5) represent the equilibrium equations of compressive and tensile forces at yield limit and maximum load limit state, respectively. The nominal moment capacities of a hybrid composite beam at yield limit and maximum load limit state are calculated by (4) and (6), respectively. Figures 14 and 15 represent strain and stress diagram at yield limit and maximum load limit state, respectively. In both figures, black color indicates steels and reinforcement rebars were plasticized (yielded) while white color represents structural members remained elastic. The structural quantity required by apartment buildings with hybrid composite frames was obtained from (6) and compared with that of conventional buildings with bearing walls as shown in Table 5. These 
TABLE 5: Evaluation of structural systems.

\begin{tabular}{|c|c|c|c|c|c|c|c|c|c|c|}
\hline \multirow{3}{*}{$\begin{array}{l}\begin{array}{l}\text { Building } \\
\text { component }\end{array} \\
\text { Concrete } \\
\text { (H.P.F. = } 35 \mathrm{MPa} \\
\text { B.W. = } 25 \mathrm{MPa} \text { ) }\end{array}$} & \multirow{2}{*}{$\begin{array}{l}\text { System } \\
\text { H.P.F. }\end{array}$} & \multirow{2}{*}{$\begin{array}{c}\text { Gross area } \\
9236 \mathrm{~m}^{2}\end{array}$} & \multicolumn{2}{|c|}{ Building material } & \multicolumn{2}{|c|}{$\mathrm{CO}_{2}$ emission } & \multicolumn{2}{|c|}{ Energy consumption } & \multicolumn{2}{|c|}{$\mathrm{Cr}^{6+}$ emission } \\
\hline & & & $0.38 \mathrm{~m}^{3} / \mathrm{m}^{2}$ & $\begin{array}{c}69.1 \% \\
(-30.9 \%)\end{array}$ & $136.2 \mathrm{~kg}-\mathrm{CO}_{2} / \mathrm{m}^{2}$ & $\begin{array}{c}77.5 \% \\
(-22.5 \%)\end{array}$ & $1006.0 \mathrm{MJ} / \mathrm{m}^{2}$ & $\begin{array}{c}78.6 \% \\
(-21.4 \%)\end{array}$ & $1106.2 \mathrm{mg} / \mathrm{m}^{2}$ & $\begin{array}{c}68.9 \% \\
(-31.1 \%)\end{array}$ \\
\hline & B.W. & $13 \mathrm{~m}^{2}$ & $0.55 \mathrm{~m}^{3} / \mathrm{m}^{2}$ & $100.0 \%$ & $175.8 \mathrm{~kg}-\mathrm{CO}_{2} / \mathrm{m}^{2}$ & $100.0 \%$ & 1279.6 & $100.0 \%$ & 1606. & $100 \%$ \\
\hline \multirow[t]{2}{*}{ Reinforcements } & $\mathrm{H}$ & & 0.531 & $\begin{array}{c}72.6 \% \\
(-27.4 \%)\end{array}$ & $144.5 \mathrm{~kg}-\mathrm{CO}_{2} / \mathrm{m}^{2}$ & $\begin{array}{c}72.4 \% \\
(-27.6 \%)\end{array}$ & $1931.4 \mathrm{MJ} / \mathrm{m}^{2}$ & $\begin{array}{r}71.3 \\
(-28\end{array}$ & - & - \\
\hline & B.W. & $13 \mathrm{~m}^{2}$ & $0.73 \mathrm{kN} / \mathrm{m}^{2}$ & $100.0 \%$ & $199.6 \mathrm{~kg}-\mathrm{CO}_{2} / \mathrm{m}^{2}$ & $100.0 \%$ & $2710.7 \mathrm{MJ} / \mathrm{m}^{2}$ & $100.0 \%$ & - & - \\
\hline \multirow{2}{*}{ Steel section } & H.P.F. & $9236 \mathrm{~m}^{2}$ & $0.07 \mathrm{kN} / \mathrm{m}^{2}$ & $100.0 \%$ & $20.6 \mathrm{~kg}-\mathrm{CO}_{2} / \mathrm{m}^{2}$ & $100.0 \%$ & $272.1 \mathrm{MJ} / \mathrm{m}^{2}$ & $100.0 \%$ & - & - \\
\hline & B.W. & $6513 \mathrm{~m}^{2}$ & $-\mathrm{kN} / \mathrm{m}^{2}$ & $-\%$ & $-\mathrm{kg}-\mathrm{CO}_{2} / \mathrm{m}^{2}$ & $-\%$ & $-\mathrm{MJ} / \mathrm{m}^{2}$ & $-\%$ & - & - \\
\hline
\end{tabular}

${ }^{*}$ H.P.F.: hybrid precast frames; B.W.: bearing wall.

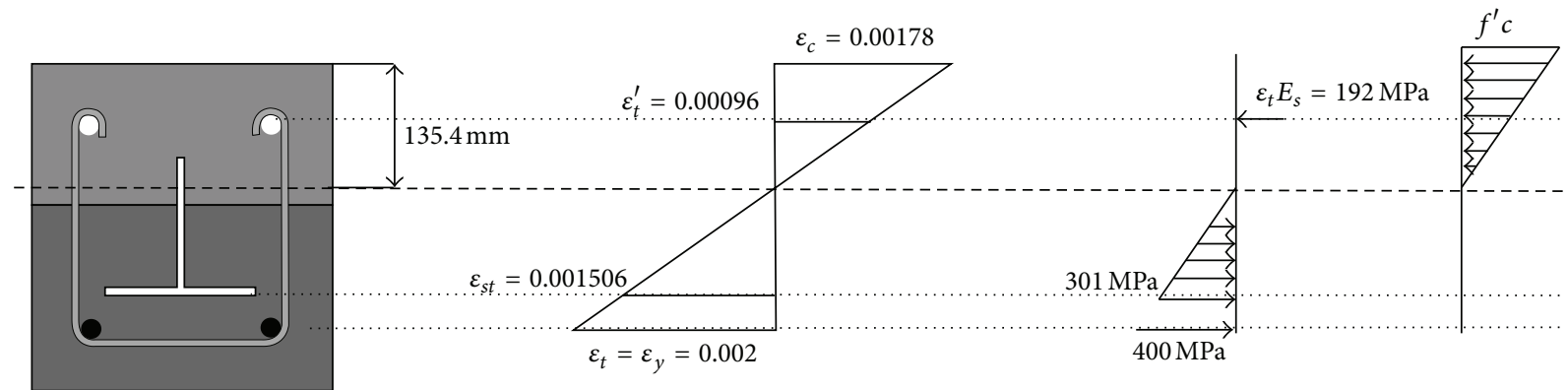

FIGURE 14: Strain and stress diagram at yield limit state.



FIGURE 15: Strain and stress diagram at maximum load limit state.

equations would help engineer estimate precise construction materials and understand how buildings with hybrid composite frames behave. Consider

$$
\begin{aligned}
\alpha=\left(\int_{0}^{0.002} f_{c}^{\prime}\left\{\frac{2 \varepsilon_{c}}{\varepsilon_{c o}}-\left(\frac{\varepsilon_{c}}{\varepsilon_{c o}}\right)^{2}\right\} d \varepsilon_{c}\right. \\
\left.+\int_{0.002}^{0.003} f_{c}^{\prime}\left\{1-100\left(\varepsilon_{c}-\varepsilon_{c o}\right)\right\} d \varepsilon_{c}\right) \\
\times\left(f_{c}^{\prime} \varepsilon_{c m}\right)^{-1}, \\
\gamma=1-\left(\left(\int_{0}^{0.002} \varepsilon_{c} f_{c}^{\prime}\left\{\frac{2 \varepsilon_{c}}{\varepsilon_{c o}}-\left(\frac{\varepsilon_{c}}{\varepsilon_{c o}}\right)^{2}\right\} d \varepsilon_{c}\right.\right. \\
\left.+\int_{0.002}^{0.003} \varepsilon_{c} f_{c}^{\prime}\left\{1-100\left(\varepsilon_{c}-\varepsilon_{c o}\right)\right\} d \varepsilon_{c}\right)
\end{aligned}
$$

$$
\begin{aligned}
\times\left(\varepsilon_{c m}\right. & {\left[\int_{0}^{0.002} f_{c}^{\prime}\left\{\frac{2 \varepsilon_{c}}{\varepsilon_{c o}}-\left(\frac{\varepsilon_{c}}{\varepsilon_{c o}}\right)^{2}\right\} d \varepsilon_{c}\right.} \\
& \left.\left.\left.+\int_{0.002}^{0.003} f_{c}^{\prime}\left\{1-100\left(\varepsilon_{c}-\varepsilon_{c o}\right)\right\} d \varepsilon_{c}\right]\right)^{-1}\right)
\end{aligned}
$$

$$
\begin{aligned}
\alpha f_{c}^{\prime} b c & +A_{s}^{\prime} E_{s} \frac{\varepsilon_{c}}{c}\left(c-d^{\prime \prime}\right)+\frac{1}{2} A_{w}^{\prime} E_{s} \frac{\varepsilon_{c}}{c}\left(c-d^{\prime \prime \prime}\right) \\
= & A_{s} F_{y}+A_{f} E_{s} \frac{\varepsilon_{c}}{c}\left(d-c-d^{\prime}-\frac{t_{f}}{2}\right) \\
& +\frac{1}{2} A_{w} E_{s} \frac{\varepsilon_{c}}{c}\left(d-c-d^{\prime}-t_{f}\right),
\end{aligned}
$$

where $A_{w}^{\prime}=t_{w}\left(c-d^{\prime \prime \prime}\right), A_{w}=t_{w}\left(d-c-d^{\prime}-t_{f}\right)$

$$
\begin{aligned}
M_{n}= & \alpha f_{c}^{\prime} b c(c-\gamma c)+A_{s}^{\prime} E_{s} \frac{\varepsilon_{c}}{c}\left(c-d^{\prime \prime}\right)^{2} \\
& +\frac{1}{3} A_{w}^{\prime} E_{s} \frac{\varepsilon_{c}}{c}\left(c-d^{\prime \prime \prime}\right)^{2}+A_{s} F_{y}(d-c)
\end{aligned}
$$




\begin{tabular}{|c|c|c|c|c|c|c|c|}
\hline \multirow{2}{*}{ Process } & \multicolumn{7}{|c|}{ One floor } \\
\hline & Day 1 & Day 2 & Day 3 & Day 4 & Day 5 & Day 6 & Day 7 \\
\hline \multicolumn{8}{|l|}{ Marking } \\
\hline \multicolumn{8}{|l|}{ Rebar work (wall) } \\
\hline \multicolumn{8}{|l|}{ Wall form installation } \\
\hline \multicolumn{8}{|l|}{ Slab form installation } \\
\hline \multicolumn{8}{|l|}{ Rebar work (slab) } \\
\hline \multicolumn{8}{|l|}{$\begin{array}{l}\text { Electrical and mechanical } \\
\text { facilities (slab) }\end{array}$} \\
\hline Cleaning and pouring & & & & & & & \\
\hline
\end{tabular}

FIGURE 16: Processes for constructing one floor of a conventional wall-type apartment building [20].

$$
\begin{aligned}
& +A_{f} E_{s} \frac{\varepsilon_{c}}{c}\left\{\left(d-c-d^{\prime}-t_{f}\right)\left(d-c-d^{\prime}-\frac{t_{f}}{2}\right)\right. \\
& \left.+\frac{t_{f}}{2}\left(d-c-d^{\prime}-\frac{t_{f}}{3}\right)\right\} \\
& +\frac{1}{3} A_{w} E_{s} \frac{\varepsilon_{c}}{c}\left(d-c-d^{\prime}-t_{f}\right)^{2},
\end{aligned}
$$

where $A_{w}^{\prime}=t_{w}\left(c-d^{\prime \prime \prime}\right), A_{w}=t_{w}\left(d-c-d^{\prime}-t_{f}\right)$

$$
\begin{gathered}
\alpha f_{c}^{\prime} b c+A_{s}^{\prime} E_{s} \frac{\varepsilon_{c}}{c}\left(c-d^{\prime \prime}\right)+\frac{1}{2} A_{w}^{\prime} E_{s} \frac{\varepsilon_{c}}{c}\left(c-d^{\prime \prime \prime}\right) \\
=A_{s} F_{y}+A_{f} F_{y}+A_{w p} F_{y}+\frac{1}{2} A_{w n y} E_{s} \varepsilon_{s y}
\end{gathered}
$$

where $A_{w}^{\prime}=t_{w}\left(c-d^{\prime \prime \prime}\right), A_{w p}=t_{w}\left\{\left(d-c+d^{\prime}+t_{f}\right)+\left(\varepsilon_{s y} / \varepsilon_{c}\right) c\right\}$, $A_{w n y}=t_{w}\left(\varepsilon_{s y} / \varepsilon_{c}\right) c$

$$
\begin{aligned}
M_{n}= & \alpha f_{c}^{\prime} b c(c-\gamma c)+A_{s}^{\prime} E_{s} \frac{\varepsilon_{c}}{c}\left(c-d^{\prime \prime}\right)^{2} \\
& +\frac{1}{3} A_{w}^{\prime} E_{s} \frac{\varepsilon_{c}}{c}\left(c-d^{\prime \prime \prime}\right)^{2}+A_{s} F_{y}(d-c) \\
& +A_{f} F_{y}\left(d-c-d^{\prime}-\frac{t_{f}}{2}\right) \\
& +\frac{1}{2} A_{w p} F_{y}\left\{\left(d-c-d^{\prime}-t_{f}\right)+\frac{\varepsilon_{s y}}{\varepsilon_{c}} c\right\} \\
& +\frac{1}{3} A_{w n y} E_{s} \frac{\left(\varepsilon_{s y}\right)^{2}}{\varepsilon_{c}} c,
\end{aligned}
$$

where $A_{w}^{\prime}=t_{w}\left(c-d^{\prime \prime \prime}\right), A_{w p}=t_{w}\left\{d-\left(c+d^{\prime}+\left(\varepsilon_{s y} / \varepsilon_{c}\right) c\right)\right\}$, $A_{w n y}=t_{w}\left(\varepsilon_{s y} / \varepsilon_{c}\right) c$.

A completed bearing wall apartment building was selected for this comparison. Apartment buildings with hybrid precast frames and bearing wall frames were evaluated in terms of building material, $\mathrm{CO}_{2}$ emission, energy consumption, and $\mathrm{Cr}^{6+}$ emission shown in Table 5. Construction materials per square meters were calculated based on (5) and (6) which were then used to calculate the quantities of Table 5.

The building materials of concrete and reinforcements of apartment buildings with hybrid precast frames were reduced by $31 \%$ and $27 \%$, respectively, compared with that of bearing wall frame buildings. The $\mathrm{CO}_{2}$ emission, energy consumption, and $\mathrm{Cr}^{6+}$ emission of apartment buildings with hybrid precast frames were also decreased compared with bearing wall frame buildings as shown in Table 5, exhibiting the efficiency of using gravity hybrid precast frames for apartment buildings.

\section{Reduction in Construction Schedule}

Figures 16 and 17 compare the construction time frames based on the use of conventional bearing walls versus the proposed hybrid frames.

The construction time is the sum of each critical path, as shown in

$$
\sum_{i=1}^{n}\left(\mathrm{CA}_{i}\right)=\mathrm{CA}_{1}+\mathrm{CA}_{2}+\mathrm{CA}_{3}+\mathrm{CA}_{4} \cdots .
$$

The critical paths that affect construction time for a bearing wall apartment are $\mathrm{CA}_{1}$ (marking, 1 day), $\mathrm{CA}_{2}$ (rebar work, wall, 1 day), $\mathrm{CA}_{3}$ (wall form installation, 2 days), $\mathrm{CA}_{4}$ (slab form installation, 1 day), $\mathrm{CA}_{5}$ (rebar work, slab, 1 day), and $\mathrm{CA}_{6}$ (cleaning and pouring, 1 day). Installation of electrical and mechanical facilities at the slab is performed with rebar work of the slab and takes less time than that of rebar work. Electrical and mechanical facilities at the slab are therefore excluded from the critical path. The construction time per floor is seven days based on (7). The critical paths affecting construction time for an apartment building using hybrid frames are $\mathrm{CA}_{1}$ (rebar work, core wall, 0.5 days), $\mathrm{CA}_{2}$ (column-beam unit installation (1 day), beam unit installation (1.5 days)), $\mathrm{CA}_{3}$ (rebar work, slab, 0.5 days), and $\mathrm{CA}_{4}$ (cleaning and pouring, 0.5 days). Column-beam unit installation and beam unit installation are carried out alternately. Beams are only installed at every second and third floor since columns are erected as a three-story unit. 


\begin{tabular}{|c|c|c|c|c|c|c|c|c|c|c|}
\hline \multirow[b]{2}{*}{ Process } & \multicolumn{4}{|c|}{ First floor } & \multicolumn{3}{|c|}{ Second floor } & \multicolumn{3}{|c|}{ Third floor } \\
\hline & Day 1 & Day 2 & Day 3 & Day 4 & Day 5 & Day 6 & Day 7 & Day 8 & Day 9 & Day 10 \\
\hline Rebar work (core wall) & 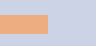 & & & & 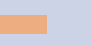 & & & 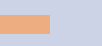 & & \\
\hline Core wall form installation & 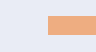 & 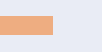 & & & - & 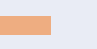 & & 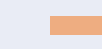 & 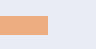 & \\
\hline $\begin{array}{l}\text { Column-beam unit } \\
\text { installation }\end{array}$ & E & & & & & & & & & \\
\hline Beam unit installation & 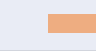 & & & & 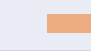 & & & 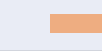 & & \\
\hline Deck plate installation & & 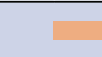 & + & & & & & & & \\
\hline Joint form installation & & 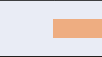 & & 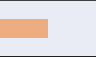 & &  & 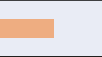 & & 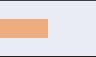 & 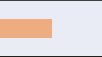 \\
\hline Rebar work (slab) & & & & 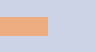 & & 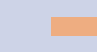 & 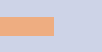 & & 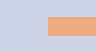 & 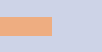 \\
\hline $\begin{array}{c}\text { Electrical and mechanical } \\
\text { facilities (slab) }\end{array}$ & & & & 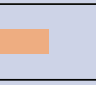 & & & 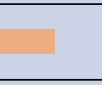 & & & 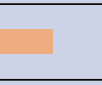 \\
\hline Cleaning and pouring & & & & & & & & & & \\
\hline
\end{tabular}

FIGURE 17: Processes for constructing three floors of an apartment building using hybrid frames [20].

TABLE 6: Comparative analysis of the construction period [20]

\begin{tabular}{lccc}
\hline $\begin{array}{l}\text { Structural } \\
\text { type }\end{array}$ & $\begin{array}{c}\text { Typical } \\
\text { floor }\end{array}$ & $\begin{array}{c}\text { 30-story apartment } \\
\text { building }\end{array}$ & Comparison \\
\hline $\begin{array}{l}\text { Bearing wall } \\
\text { Hybrid precast }\end{array}$ & $\begin{array}{c}10 \text { days } / 1 \text { floor } \\
\text { floors }\end{array}$ & 210 Days & $100.0 \%$ \\
frame & 100 Days & $47.6 \%$ \\
\hline
\end{tabular}

As a result of the critical paths analysis, the construction time per floor is four days for the first floor and three days for the next two floors, requiring ten days for the construction of three floors utilizing columns of a threestory unit. The time for frame erection was reduced by $52 \%$ when using hybrid frames, highlighting their economic and construction benefits. Erection of structural frames for one floor using conventional bearing walls involves rebar work and concrete pouring and requires about seven days, as shown in Figure 16. In contrast, only three days were required to install wall and slab forms, indicating that the overall construction was influenced by form work, which is highly dependent on work skill. However, erection of three floors with hybrid precast frames required only ten days when three-story hybrid precast columns were erected at one lift. The significant reduction in form work contributed to the decrease in overall construction time obtained when using the hybrid precast frames, as shown in Figure 17. As shown in Table 6, frame erection of a 30-story building required seven days per floor or 210 days for the entire building when using conventional bearing walls. However, only ten days per three floors (or 100 days for the entire building) were required for frame erection of the building with hybrid precast frames, which corresponds to a $52.4 \%$ reduction in frame erection time.

\section{Conclusions}

This study described and characterized an optimized hybrid precast composite structural system for gravity system. Major contributions are summarized below.

(1) Gravity hybrid precast frames were presented. These hybrid frames consist of precast concrete and steel which can be erected at a speed similar to that of steel frames. Steel sections inserted in precast columns and beams are used as erection steel components.

(2) Mathematical model of gravity hybrid precast beam was presented at yield limit state and maximum load limit state. Neutral axis of postyield state found from equilibrium equations was used to calculate nominal moment capacities of a hybrid composite beam at both limit state.

(3) The new building frame systems for gravity loadings fabricated with hybrid precast composite frames consisting of simple connections between columns and beams were proposed in this paper. The dual frame systems of moment connections with much more complicated construction details required significant time and costs than that of building frame systems of gravity loadings. However, the gravity hybrid precast composite structures will provide simplified construction method, while enhancing economy during construction. The reductions of construction resources including concrete and reinforcements (31\% reduction of concrete and $27 \%$ reduction of reinforcements) were achieved when apartments were to be built with hybrid precast frames.

(4) The gravity hybrid precast frames use less construction materials than conventional frames and therefore reduce carbon dioxide and hazardous substance emissions compared to conventional frames. It was 
observed the efficiency of using gravity hybrid precast frames for apartment building which decreased the $\mathrm{CO}_{2}$ emission (23\% reduction of concrete and $28 \%$ reduction of reinforcements), energy consumption (21\% reduction of concrete and $29 \%$ reduction of reinforcements), and $\mathrm{Cr}^{6+}$ emission compared with bearing wall frame buildings. The use of gravity hybrid precast frames was demonstrated to provide better solutions for environments and economy than that of conventional buildings.

(5) Dynamic analysis of a 15-story building designed with the proposed composite gravity frames was performed to characterize frequencies and mode shapes of the building for seismic design purposes.

\section{Conflict of Interests}

The authors declare that there is no conflict of interests regarding the publication of this paper.

\section{Acknowledgment}

This work was supported by Grant from the Kyung Hee University in 2013 (KHU-20130363).

\section{References}

[1] J. F. Hajjar, "Composite steel and concrete structural systems for seismic engineering," Journal of Constructional Steel Research, vol. 58, no. 5-8, pp. 703-723, 2002.

[2] G. Fabbrocino, G. Manfredi, and E. Cosenza, "Ductility of composite beams under negative bending: an equivalence index for reinforcing steel classification," Journal of Constructional Steel Research, vol. 58, no. 2, pp. 185-202, 2001.

[3] B. Yang and K. Tan, "Behaviour of composite beam-column joints under a middle-column-removal scenario: experimental tests," Journal of Structural Engineering, vol. 140, no. 2, Article ID 04013045, 2014.

[4] L. Tesser and R. Scotta, "Flexural and shear capacity of composite steel truss and concrete beams with inferior precast concrete base," Engineering Structures, vol. 49, pp. 135-145, 2013.

[5] H. J. Hwang, H. G. Park, C. H. Lee et al., "Seismic resistance of concrete-filled U-shaped steel beam-to-RC column connections," Journal of Korean Society of Steel Construction, vol. 23, pp. 83-97, 2011.

[6] J. Hassan and B. Khosrow, "Nonlinear seismic behavior evaluation of ductile beam-column connections in precast concrete," International Journal of Civil and Structural Engineering, vol. 1, pp. 445-453, 2011.

[7] A. M. Ioani and E. Tripa, "Structural behavior of an innovative all-precast concrete dual system for residential buildings," $P C I$ Journal, vol. 57, no. 1, pp. 110-123, 2012.

[8] C. Chou and C. Uang, "Effects of continuity plate and transverse reinforcement on cyclic behavior of SRC moment connections," Journal of Structural Engineering, vol. 133, no. 1, pp. 96-104, 2007.

[9] Y. K. Ju and S. D. Kim, "Structural behavior of alternative low floor height system using structural "tee," half precast concrete, and horizontal stud," Canadian Journal of Civil Engineering, vol. 32, no. 2, pp. 329-338, 2005.
[10] X. Wang, M. Truijens, L. Hou, Y. Wang, and Y. Zhou, "Integrating augmented reality with building information modeling: onsite construction process controlling for liquefied natural gas industry," Automation in Construction, vol. 40, pp. 96-105, 2014.

[11] L. Hou, Y. Wang, X. Wang et al., "Combining photogrammetry and augmented reality towards an integrated facility management system for the oil industry," Proceedings of the IEEE, vol. 102, no. 2, pp. 204-220, 2014.

[12] L. Hou, X. Wang, L. Bernold, and P. E. D. Love, "Using animated augmented reality to cognitively guide assembly," Journal of Computing in Civil Engineering, vol. 27, no. 5, pp. 439-451, 2013.

[13] Y. Wang, X. Wang, J. Wang, P. Yung, and G. Jun, "Engagement of facilities management in design stage through BIM: framework and a case study," Advances in Civil Engineering, vol. 2013, Article ID 189105, 8 pages, 2013.

[14] W. K. Hong, J. M. Kim, S. C. Park et al., "A new apartment construction technology with effective $\mathrm{CO}_{2}$ emission reduction capabilities," Energy, vol. 35, no. 6, pp. 2639-2646, 2010.

[15] W. Hong, S. Park, J. Kim et al., "Development of structural composite hybrid systems and their application with regard to the reduction of $\mathrm{CO}_{2}$ emissions," Indoor and Built Environment, vol. 19, no. 1, pp. 151-162, 2010.

[16] W. Hong, S. Jeong, S. Park, and J. T. Kim, "Experimental investigation of an energy-efficient hybrid composite beam during the construction phase," Energy and Buildings, vol. 46, pp. 37-47, 2012.

[17] G. P. Hammond and C. I. Jones, Inventory of Carbon \& Energy (ICE), Department of Mechanical Engineering, University of Bath, Bath, UK, 2008.

[18] G. P. Hammond and C. I. Jones, "Embodied energy and carbon in construction materials," Proceedings of Institution of Civil Engineers: Energy, vol. 161, no. 2, pp. 87-98, 2008.

[19] National Institute of Environment Research (NIER): Domestic and foreign cement heavy metal analysis result (May 2013), NIER, 2013, http://www.nier.go.kr/eric/portal/kor/nf/nier-nf02.page.

[20] S. Kim, W. Hong, J. Kim, and J. T. Kim, “The development of modularized construction of enhanced precast composite structural systems (Smart Green frame) and its embedded energy efficiency," Energy and Buildings, vol. 66, pp. 16-21, 2013. 


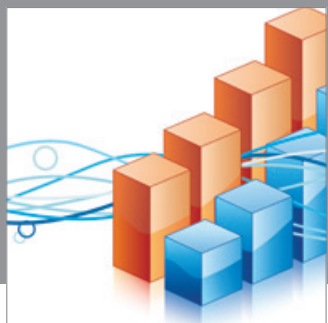

Advances in

Operations Research

mansans

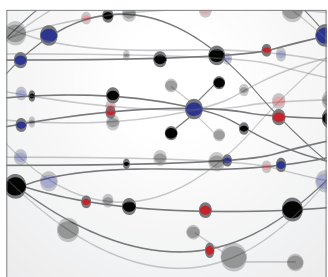

The Scientific World Journal
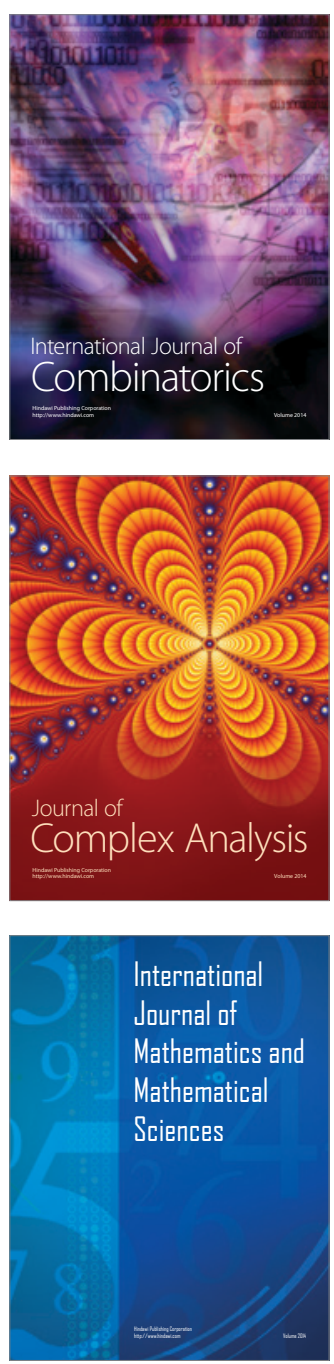
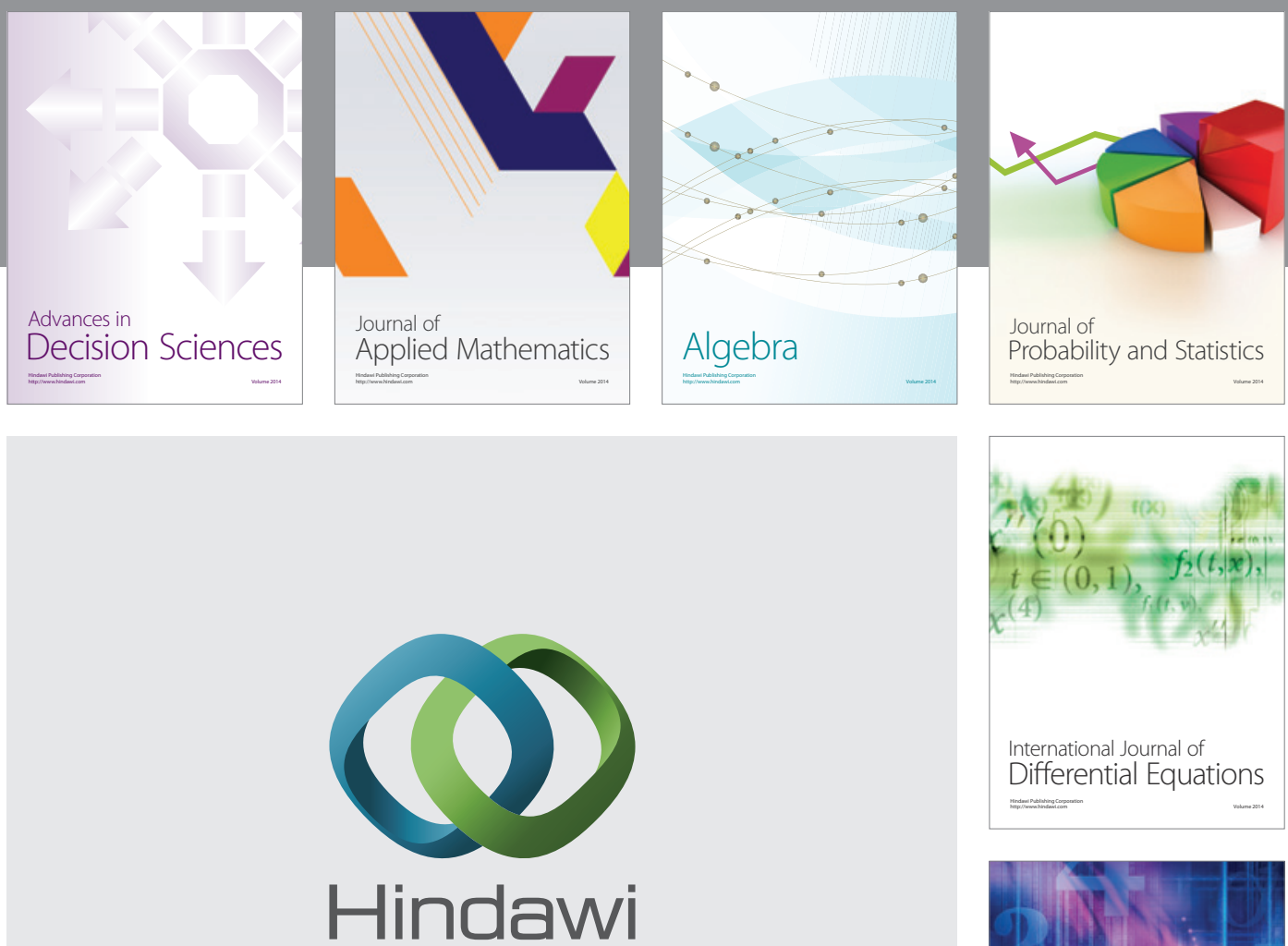

Submit your manuscripts at http://www.hindawi.com
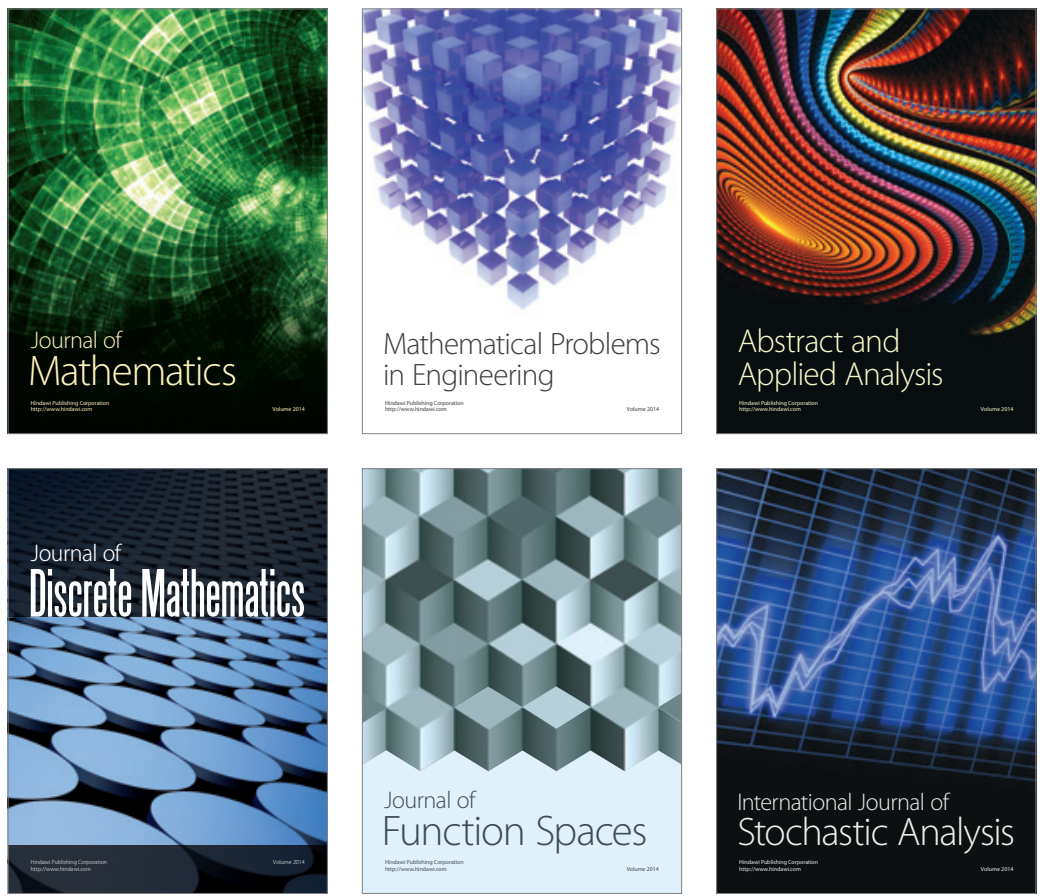

Journal of

Function Spaces

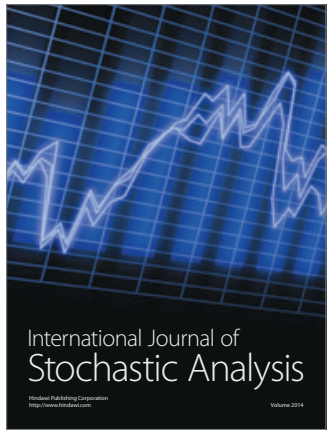

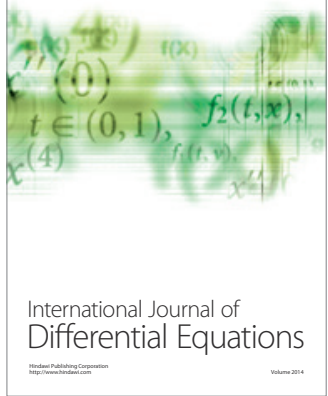
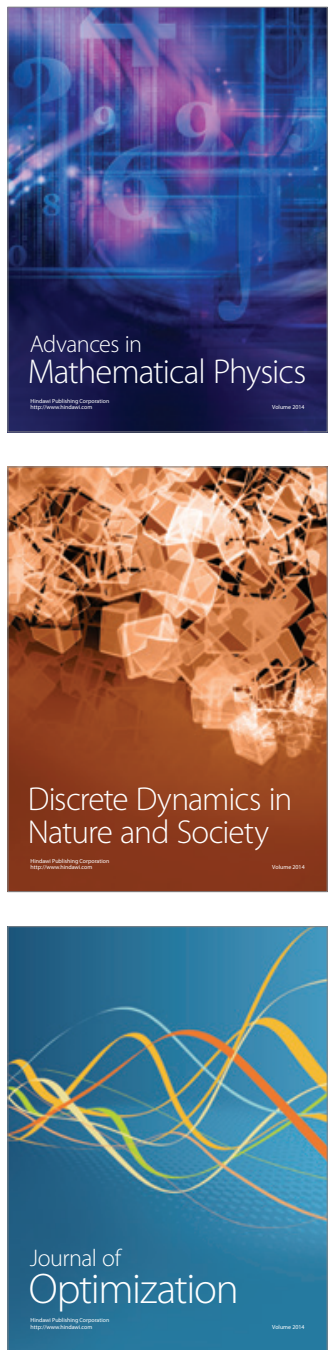